ORIGINAL ARTICLE

\title{
Acute Diarrhea in Exclusively Breast Fed Infants in relation to Zinc Level
}

\author{
RIAN MAHMOOD IBRAHIM ${ }^{1}$, NASHWAN MUSTAFA AL HAFIDH² \\ ${ }^{1}$ University of Mosul/College of Nursing, Iraq \\ 2University of Nineveh, College of Medicine, Iraq \\ Correspondence to Rian Mahmood Ibrahim Email: rianmahmood198992@uomosul.edu.iq
}

\begin{abstract}
Background: Zinc deficiency is associated with alteration in gastrointestinal tract structure, function, and impaired immune function.

Aim: To analyze the effects of zinc deficiency on the occurrence of acute diarrhea in exclusively breast-fed infants. Methods: In a case-control study, including a total of 72 exclusively breast-fed infants aged $\leq 6$ months, 34 of them with acute diarrhea were in the study group and 38 infants as the healthy control group. Demographic characteristics of all infants and their parents were studied. Serum Zinc level was measured for all participants.

Results: Zinc level had significant ( $p$-value $=0.000)$ differences between infants with acute diarrhea and the healthy control group. The mean serum zinc value \pm SEM in children with acute diarrhea was $63.11 \pm 1.7$ which was significantly $(p=0.000)$ different from the mean serum zinc value \pm SEM $(78.6 \pm 1.6)$ in healthy infants. A cut-off value $60.6 \mu \mathrm{g} / \mathrm{dl}$ of total serum zinc level was significantly $(p=0.000)$ associated with a sensitivity of $100 \%$ with the occurrence of acute diarrhea among exclusively breast-fed infants.

Conclusions: Low serum zinc level is associated with the occurrence of acute diarrhea in exclusively breast-fed infants. A cutoff serum zinc value of $60.6 \mu \mathrm{g} / \mathrm{dl}$ has $100 \%$ sensitivity with the occurrence of acute diarrhea among breast-fed infants.
\end{abstract}

Keywords: Zinc deficiency, diarrhea, infants, breastfeeding

\section{INTRODUCTION}

Zinc is an essential nutrientthat affects the immune systemfunction,furthermore zinc acts as a cofactor for numerous enzymes. The World Health Organization (WHO) considers zinc deficiency as a universalchallenge; more than half a million deaths in children under 5 years of age are due to zinc deficiency, ( Aumeistere etal.,2018).

The World Health Organization defines exclusive breastfeeding as when "an infant receives only breast milk, no other liquids or solids are given - not even water, with the exception of oral rehydration solution, or drops/syrups of vitamins, minerals or medicines" (World Health Organization 2016). For breast- fed infants ; Breast milk is the sole source of food (and accordingly, the zinc source) for infants $\leq$ six months of life; zinc consumption from breast milk for for infants $\leq$ six months of of age can be lower than the recommended(Winiarska-Mieczan et al.,2014), (Javad, M. T et al.,2018), and (Qian, J. et al.,2010).

According to $\mathrm{WHO}$, diarrhea is described as three unusually loose or watery stools in less than 24 hours, acute diarrhea is described as diarrhea that lasts less than 14 days, (O. F. Afolabi et al., 2018).

This study aimed to analyze the effects of zinc deficiency on the occurrence of acute diarrhea in an exclusively breastfed infant aged $\leq 6$ months.

\section{PATIENTS AND METHODS}

The sample included 72 breastfed children who lived in Nineveh governorate and aged $\leq$ six-month. The case group, constituted 34 infants with acute diarrhea studied at Al-Khansa Pediatric Teaching Hospital, whereas 38 infants in the healthy control group were enrolled from convenient patients visiting Talekif primary health care center for vaccination. Demographic characteristics of the children and their parents were studied. Serum Zinc level was measured for all participants.

Criteria for inclusion of case group

1. Exclusively breast fed infant

2. Children aged $\leq$ six months with acute diarrhea (periods of diarrhea are shorter than or equal to 14 days).

3. During the data collection time, mothers and children are available.

4. Written acceptance of the mother to engage in the research.

Criteria for inclusion of the healthy control group

1. Exclusively breast fed infant

2. Children aged $\leq$ six months who were well and eligible for vaccination as determined by their primary care physician.

3. Mothers and children are available during the data collection period.

4. The mother's written consent to participate in the study.

Criteria for Exclusion of case and the healthy control groups:-

1- Children who have been diagnosed with a chronic disease.

2- Children with congenital abnormalities.

3-Children who have been taking zinc supplements for at least three months.

4- Dysmorphic children.

5-Mothers refused to fill out the questionnaire.

Laboratory measurement:: For the calculation of zinc levels, two milliliters of blood were taken from each child in the case and healthy control groups. The zinc levels were calculated using atomic absorption spectrometry. The used 
instrument was an Emclab spectrophotometer, Manufactured in Germany, the Kit name is ZINCO serial number is ETCC02750.1.0, and the normal range of serum zinc was $(70-140 \mu \mathrm{g} / \mathrm{dl})$. SPSS version 26 was used to evaluate the data. When comparing categorical variables, the Chi-square test was used. For numerical results, the Ttest was employed. Receiver operating characteristic (ROC) analysis was applied to estimate the zinc cutoff value. A $P$-value of $\leq 0.05$ was considered significant.

\section{RESULTS}

Table 1 shows that there were no significant ( $p$ value $=0.903,0.374$ ) statistical differences between case and control groups; regarding, gender, and order of the child in the family. That there were no significant statistical differences between case and control groups; regarding studied parental variables; father's age, mother age, mother occupation, mother marital status, and father occupation respectively

$(p-$ value $=0.364,0.468,0.602,0.775,0.318$ )

Table 2 Showed a significant ( $p$-value=0.000) difference in serum zinc level between breast-fed infants with acute diarrhea and breast-fed healthy control infants.

Table 3 Shows that the mean of serum zinc value $\pm S E M$ in breast feeding children with acute diarrhea was 63.11 1.70 , which was significantly $(p=0.000)$ different from the mean of serum zinc value \pm SEM $(78.647 \pm 1.63)$ in breast fed healthy children .

Depending on the analyzed ROC findings, Receiver operating characteristic (ROC) analysis showed the area under the curve of $0.867 \pm$ SE 0 .041 , a cut off value of $60.6 \mu \mathrm{g} / \mathrm{dl}$ of zinc was significantly $(p=.000)$ associated with sensitivity of $100 \%$ and a 1 - specificity of $0.59 \%$ with the occurrence of acute diarrhea in breastfed children (Table 4, Figure 1).

Table 1: Demographic characteristics of thestudied infants $(n=72)$, and theirparent.

\begin{tabular}{|c|c|c|c|c|c|}
\hline Variable & No & $\%$ & No & $\%$ & $P$ value \\
\hline \multicolumn{6}{|l|}{ Gender } \\
\hline Male & 21 & 46.7 & 24 & 53.3 & \multirow[t]{2}{*}{0.903} \\
\hline Female & 13 & 48.1 & 14 & 51.9 & \\
\hline \multicolumn{6}{|c|}{ Order of the child in the family } \\
\hline First & 9 & 34.6 & 17 & 65.4 & \multirow[t]{4}{*}{0.374} \\
\hline Second & 10 & 52.6 & 9 & 47.4 & \\
\hline Third & 7 & 63.6 & 4 & 36.4 & \\
\hline Fourth and above & 8 & 50 & 8 & 50 & \\
\hline \multicolumn{6}{|l|}{ Father age(year) } \\
\hline$<18$ & 0 & 0 & 1 & 100 & \multirow[t]{4}{*}{0.364} \\
\hline $19-29$ & 17 & 41.5 & 24 & 58.5 & \\
\hline 30-39 & 15 & 60 & 10 & 40 & \\
\hline$>40$ & 2 & 40 & 3 & 60 & \\
\hline \multicolumn{6}{|l|}{ Mother age (year) } \\
\hline$<18$ & 3 & 30 & 7 & 70 & \multirow[t]{4}{*}{0.468} \\
\hline 19-29 & 22 & 47.8 & 24 & 52.2 & \\
\hline 30-39 & 8 & 53.3 & 7 & 46.7 & \\
\hline$>40$ & 1 & 100 & 0 & 0 & \\
\hline \multicolumn{6}{|l|}{ Mother occupation } \\
\hline House wife & 27 & 45.8 & 32 & 54.2 & \multirow[t]{3}{*}{0.602} \\
\hline Employee & 3 & 42.9 & 4 & 57.1 & \\
\hline Worker & 4 & 66.7 & 2 & 33.3 & \\
\hline \multicolumn{6}{|c|}{ Mother marital status } \\
\hline Married & 31 & 48.4 & 33 & 51.6 & \multirow[t]{3}{*}{0.775} \\
\hline Divorce & 1 & 50 & 1 & 50 & \\
\hline Widow & 2 & 33.3 & 4 & 66.7 & \\
\hline \multicolumn{6}{|l|}{ Father occupation } \\
\hline Does not work & 2 & 50 & 2 & 50 & \multirow[t]{7}{*}{0.318} \\
\hline Unskilled Worker & 15 & 50 & 15 & 50 & \\
\hline Semi-skilled worker & 12 & 57.1 & 9 & 42.9 & \\
\hline Skilled Worker & 2 & 18.2 & 9 & 81.8 & \\
\hline Writer & 0 & 0 & 0 & 0 & \\
\hline Semi-professional & 1 & 100 & 0 & 0 & \\
\hline Professional & 2 & 40 & 3 & 60 & \\
\hline
\end{tabular}


Table 2: Comparison between cases with acute diarrhea and healthy control breast - fed children in relation to their zinc level.

\begin{tabular}{|c|c|c|c|c|c|c|}
\hline & & & \multicolumn{2}{|l|}{ Zinc level } & \multirow[t]{2}{*}{ Total } & \multirow[t]{2}{*}{ P-Value } \\
\hline & & & Normal & Low & & \\
\hline \multirow[t]{4}{*}{ Studied groups } & Cases & No & 9 & 25 & 34 & \multirow[t]{6}{*}{0.000} \\
\hline & & $\%$ & $26.5 \%$ & $73.5 \%$ & $100.0 \%$ & \\
\hline & Controls & NO & 32 & 6 & 38 & \\
\hline & & $\%$ & $84.2 \%$ & $15.8 \%$ & $100.0 \%$ & \\
\hline \multirow{2}{*}{\multicolumn{2}{|c|}{ Total }} & NO & 41 & 31 & 72 & \\
\hline & & $\%$ & $56.9 \%$ & $43.1 \%$ & $100.0 \%$ & \\
\hline
\end{tabular}

Table 3: Mean serum zinc value in breast fed children comparing study and controlgroups.

\begin{tabular}{|c|c|c|c|c|c|c|}
\hline & $\begin{array}{l}\text { Mean } \\
\text { serum } \\
\text { zinc value } \\
\mu \mathrm{g} / \mathrm{dl}\end{array}$ & SEM & $\begin{array}{l}\text { Mean serum } \\
\text { difference }\end{array}$ & \multicolumn{2}{|c|}{$\begin{array}{l}95 \% \text { Confidence Interval of the } \\
\text { Difference }\end{array}$} & p. value \\
\hline Case & 63.11 & 1.70 & \multirow[t]{2}{*}{15.54} & $\begin{array}{l}\text { Lower } \\
10.84\end{array}$ & $\begin{array}{l}\text { Upper } \\
20.23\end{array}$ & \multirow[t]{2}{*}{0.000} \\
\hline Control & 78.65 & 1.63 & & & & \\
\hline
\end{tabular}

Table 4: Receiver operating characteristic (ROC) analysis in breast feeding children, comparing cases with acute diarrhea and healthycontrolinfants.

\begin{tabular}{|c|c|c|c|c|}
\hline & \multicolumn{3}{|c|}{$\mid$} & \multicolumn{2}{|c|}{ 95\% confidence interval } \\
\hline $\begin{array}{c}\text { Area under the } \\
\text { curve }\end{array}$ & Std. Error & P value & Lower bound & Upper bound \\
\hline 0.867 & 0.041 & 0.000 & 0.786 & 0.948 \\
\hline
\end{tabular}

Figure 1: Receiver operating characteristic (ROC) of zinc value in relation to the occurrence of acute diarrhea among 72 studied children $\leq$ six-month age in breastfeeding children.

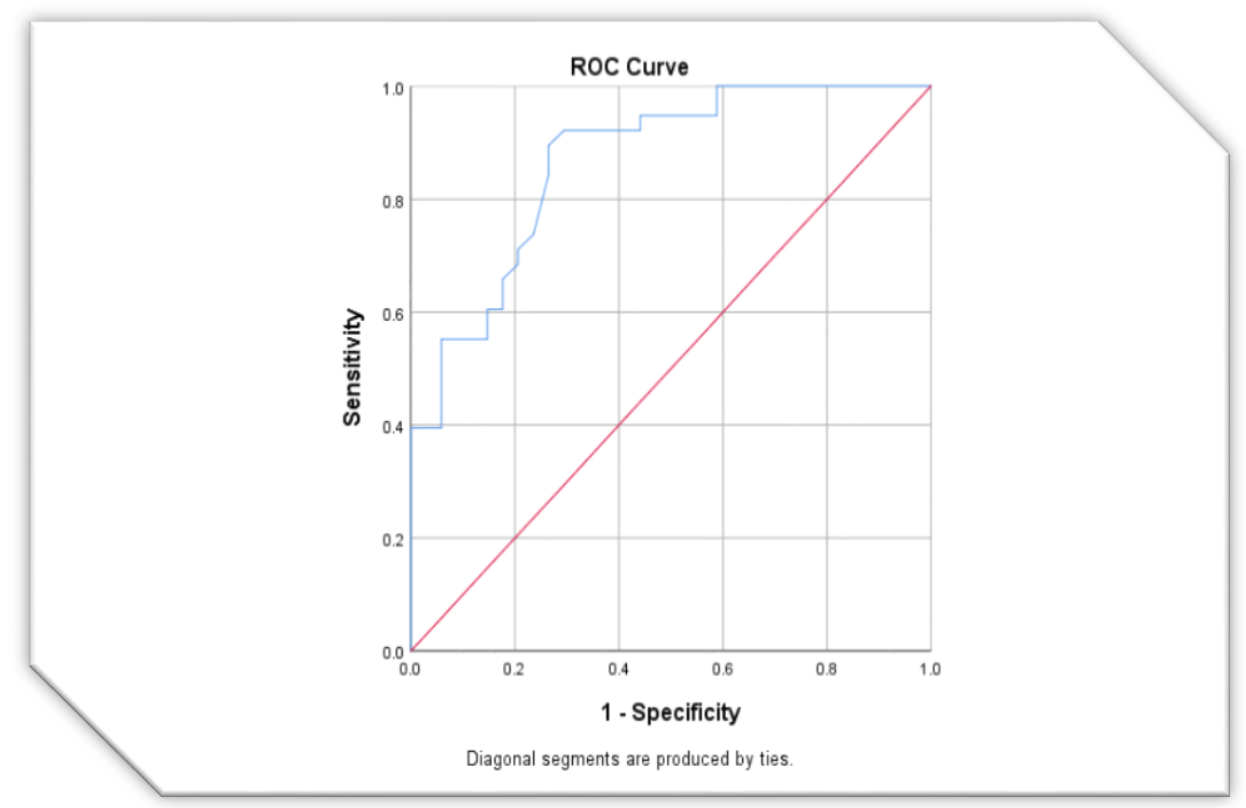




\section{DISCUSSION}

In spite of the immunological properties of breastfeedingthat decrease the incidence of acute diarrhea, diarrhea can occur inexclusively breastfed children. Diarrhea was observed in 20.33 percent of exclusively breastfed childrenfor 6 months, and 31.57 percent of children who had been breastfed for less than 6 months (Gupta et al.,2015).

Serum zinc level was low in $73.5 \%$ of studied breastfed infants with acute diarrhea; conversely, serum zinc level was normal in $84.5 \%$ of breastfed healthy control infants $(p$-value $=0.000)$. The mean serum zinc value \pm SEM in the analyzed breastfed children with acute diarrhea was $63.11 \pm 1.70$ in contrast to $(78.647 \pm 1.63)$ in breastfed healthy children $(p=0.000)$. Some studies, indicate that zinc source from breast milk for infants under six months of age can be less than the recommended value ,(Winiarska-Mieczan et al.,2014), (Javad, M. T et al.,2018), and (Qian, J. et al.,2010).The daily intake of Zinc did not fully satisfy the infant's requirements determined by WHO recommendations, (Winiarska-Mieczan, 2014).These emphasize that although breastfeeding has a well-known immunological properties, zinc has a significant protective intestinal role.

Table 4 showed depending on the analyzed ROC among breastfed children. All (100\%) of children with a total zinc level of $\leq 60.6 \mu \mathrm{g} / \mathrm{dl}$ were correctly identified as having acute diarrhea ( Figure 1). which clarify the zinc cut off value of $60.6 \mu \mathrm{g} / \mathrm{dl}$ that was significantly $(p=.000)$ associated with sensitivity of $100 \%$ of its association with the presence of acute diarrhea. This emphasizethe importance of paying an attention to the nutrition of lactating mothers; offers the lactating mother the recommended daily zinc need, in addition, to supplement the breast fed infants with recommended daily zinc dose to maintain serum zinc level above this cut off value.

According to our knowledge, this is the first research that addressed the preventive cutoff value of zinc associated with occurrence of acute diarrhea in breast-fed children aged $\leq 6$ months.

\section{CONCLUSIONS}

Serum zinc cut-off value $60.6 \mu \mathrm{g} / \mathrm{dl}$ had a significant $(p=0.000)$ association with a sensitivity of $100 \%$ with the occurrence of acute diarrhea among breast-fed infants.

Recommendation: Maintaining zinc levels among breastfed children would be an important primary preventive measure against the occurrence of acute diarrhea.

\section{REFERENCES}

1. Gupta, A., Sarker, G., Rout, A. J., Mondal, T., \& Pal, R. J. J. o. g. i. d. (2015). Risk correlates of diarrhea in children under 5 years of age in slums of Bankura, West Bengal. 7(1), 23-27.

2. Winiarska-Mieczan, A. (2014). Cadmium, lead, copper and zinc in breast milk in Poland. Biological trace element research, 157(1), 36-44.

3. Aumeistere, L., Ciproviča, I., Zavadska, D., Bavrins, K., \& Borisova, A. J. N. (2018). Zinc content in breast milk and its association with maternal diet. 10(10), 2-7.
4. Abolurin, O. O., Oyelami, O. A., \& Oseni, S. B. (2020). A comparative study of the prevalence of zinc deficiency among children with acute diarrhoea in SouthWestern Nigeria. African Health Sciences, 20(1), 406-412.

5. Afolabi, O. F., Saka, A. O., Ojuawo, A., \& Biliaminu, S. A. (2018). Serum zinc levels amongst under-five children with acute diarrhoea and bacterial pathogens. Nigerian Postgraduate Medical Journal, 25(3), 131-135.

6. Alaa, H., Shah, S. A., \& Khan, A. R. (2014). Prevalence of diarrhoea and its associated factors in children under five years of age in Baghdad, Iraq. Open Journal of Preventive Medicine, 2014.

7. Florez, I. D., Al-Khalifah, R., Sierra, J. M., Granados, C. M., Yepes-Nuñez, J. J., Cuello-Garcia, C., ... \& Thabane, L. (2016). The effectiveness and safety of treatments used for acute diarrhea and acute gastroenteritis in children: protocol for a systematic review and network metaanalysis. Systematic reviews, 5(1), 1-9.

8. Jalo, I. R., Jibo, A. M., Gajida, A. U., Kwaku, A. A., Awaisu, N., Yusuf, A. M., ... \& Abubakar, I. S. (2020). Caregiver's acceptability of zinc tablet for treatment of childhood diarrhea in rural and urban communities. Sahel Medical Journal, 23(1), 1-15.

9. Hoque, K. M., \& Binder, H. J. (2006). Zinc in the treatment of acute diarrhea: current status and assessment. Gastroenterology, 130(7), 2201-2205.

10. Koletzko, S., \& Osterrieder, S. (2009). Acute infectious diarrhea in children. Deutsches Ärzteblatt International, 106(33), 539-548.

11. Krebs, N. F., Miller, L. V., \& Michael Hambidge, K. (2014). Zinc deficiency in infants and children: a review of its complex and synergistic interactions. Paediatrics and international child health, 34(4), 279-288.

12. Laghari, G. S., Hussain, Z., \& Shahzad, H. (2019). Effect of zinc supplementation on the frequency and consistency of stool in children with acute diarrhea. Cureus, 11(3)1-5.

13. Lamberti, L. M., Walker, C. L. F., Taneja, S., Mazumder, S., \& Black, R. E. (2015). Adherence to zinc supplementation guidelines for the treatment of diarrhea among children under-five in Uttar Pradesh, India. Journal of global health, 5(2), 1-8.

14. Lazzerini, M., \& Wanzira, H. (2016). Oral zinc for treating diarrhoea in children. Cochrane database of systematic reviews, (12), 240-242.

15. Long, J. M., Mondal, P., Westcott, J. E., Miller, L. V., Islam, M. M., Ahmed, M., ... \& Krebs, N. F. (2019). Zinc absorption from micronutrient powders is low in Bangladeshi toddlers at risk of environmental enteric dysfunction and may increase dietary zinc requirements. The Journal of nutrition, 149(1), 98105.

16. McDonald, C. M., Manji, K. P., Kisenge, R., Aboud, S., Spiegelman, D., Fawzi, W. W., \& Duggan, C. P. (2015). Daily zinc but not multivitamin supplementation reduces diarrhea and upper respiratory infections in Tanzanian infants: a randomized, double-blind, placebo-controlled clinical trial. The Journal of nutrition, 145(9), 2153-2160.

17. Rodríguez-Carmona, Y., Denova-Gutiérrez, E., SánchezUribe, E., Muñoz-Aguirre, P., Flores, M., \& Salmerón, J. (2020). Zinc Supplementation and Fortification in Mexican Children. Food and nutrition bulletin, 41(1), 89-101.

18. Sharma, N., Gupta, M., Aggarwal, A. K., \& Gorle, M. (2020). Effectiveness of a culturally appropriate nutrition educational intervention delivered through health services to improve growth and complementary feeding of infants: A quasiexperimental study from Chandigarh, India. PloS one, 15(3), e0229755,1-22. 
19. Winiarska-Mieczan, A. (2014). Cadmium, lead, copper and zinc in breast milk in Poland. Biological trace element research, 157(1), 36-44.

20. Javad, M. T., Vahidinia, A., Samiee, F., Elaridi, J., Leili, M., Faradmal, J., \& Rahmani, A. (2018). Analysis of aluminum, minerals and trace elements in the milk samples from lactating mothers in Hamadan, Iran. Journal of Trace Elements in Medicine and Biology, 50, 8-15.
21. Qian, J., Chen, T., Lu, W., Wu, S., \& Zhu, J. (2010). Breast milk macro-and micronutrient composition in lactating mothers from suburban and urban Shanghai. Journal of paediatrics and child health, 46(3), 115-120.

22. World Health Organization (2016) Exclusive Breastfeeding. Available at:

23. http://www.who.int/elena/titles/exclusive breastfeeding/en/ [Accessed 